\title{
A Study on the Development of a Template Model for Linking Service Learning and School Curriculum
}

\author{
Sahoon $\mathrm{Kim}^{1}$ \\ ${ }^{1}$ Professor, College of Education, Education, HanKuk Univ. of Foreign Studies, South Korea, \\ kimsh@hufs.ac.kr \\ Corresponding author: Sahoon Kim
}

\begin{abstract}
Service learning is not just an activity. It needs to be conducted in a way that students develop their own problem-solving skills. Teachers also should understand the meaning of service learning and recognize the need for educational cooperation. However, practical cooperation is difficult. In particular, because the college entrance exam is important in schools, there are many restrictions on the realization of service learning. Considering this reality, service learning tasks should be developed into educational contents. This study was initiated by necessity in this context. The purpose of this study is to develop a highly useful template by dividing the service learning program into subject, goal, content, method, and composition. For this purpose, this study analyzed the programs conducted at the autonomous district volunteer center and practice school. As a result, this study presents templates that are easy to link course content, core competencies and activities.
\end{abstract}

Keywords: Service Learning, Volunteer Work, Curriculum Linkage, Core Competency, Program Development

\section{Introduction}

Recently, research is underway to clarify the educational phenomenon through the convergence framework[1-4]. It would be interesting to look at the phenomenon of service learning based on education. It is necessary to study volunteer activities that plan and practice activities beyond the existing passive volunteer activities. Based on this necessity, service learning with educational significance is attracting attention. Specifically, the city of Seoul has been promoting the service learning model development project since 2016, and the service learning pilot project was conducted from 2017 to 2018.

In 2019, the Seoul Volunteer Center and the Seoul Metropolitan Office of Education promoted the 'Seoul-type Student Volunteer Learning Practice School'. Practical schools tried to change the paradigm of service learning, and local communities, autonomous district volunteer centers, and schools established operational support systems.

As part of this effort, in 2019, 'a study on the development of community-connected youth service learning through analysis of Seoul-type service learning practice schools' was conducted, and learning development plans were presented to demonstrate Seoul-type student service. Through this study, the necessity of linking volunteer activities and 'curriculum content' was raised beyond administrative and procedural links.

In addition, it is necessary to find a practical survival plan for service learning in consideration of changes in the educational environment. Volunteer activities are being carried out amid changes in the

Received: March23, 2021; 1st Review Result: May 08, 2021; 2nd Review Result: July 05, 2021

Accepted: July 31, 2021 
environment that could be reduced by simplifying student records. Therefore, it is necessary to make efforts to overcome the crisis as an opportunity by promoting the realization of service learning beyond volunteer activities.

The purpose of this study is to analyze the service programs conducted by autonomous district volunteer centers and practice schools, and to develop a template with high utilization by dividing the service learning programs into subject, goal, content, method, and organization.

\section{Theoretical Background}

Volunteering is the foundation of social sustainability and trust among members[5]. The more active people are in solving community problems and helping neighbors in need, the stronger the trust and safety net of society[6]. For this reason, many school curricula encourage students to volunteer[7]. Meanwhile, for the changing future generations, schools and students should break away from the existing passive volunteer activities and engage in volunteer activities to discover, plan, and practice community problems on their own[8].

The concept of service learning began to be used in the late 1960s[9]. Service learning emphasizes the interaction, reflection and curricular connections between volunteers and beneficiaries. Reciprocity means that students and beneficiaries are equal. To this end, service learning must actually promote student learning and growth

Service learning can be implemented by applying Colb's empirical learning theory model. According to this model, service learning should be considered as a new paradigm. In other words, service learning should include educational activities such as experimentation, concrete experience, and reflection. According to the model, volunteering should include educational activities such as experiments, specific experiences, and reflections.

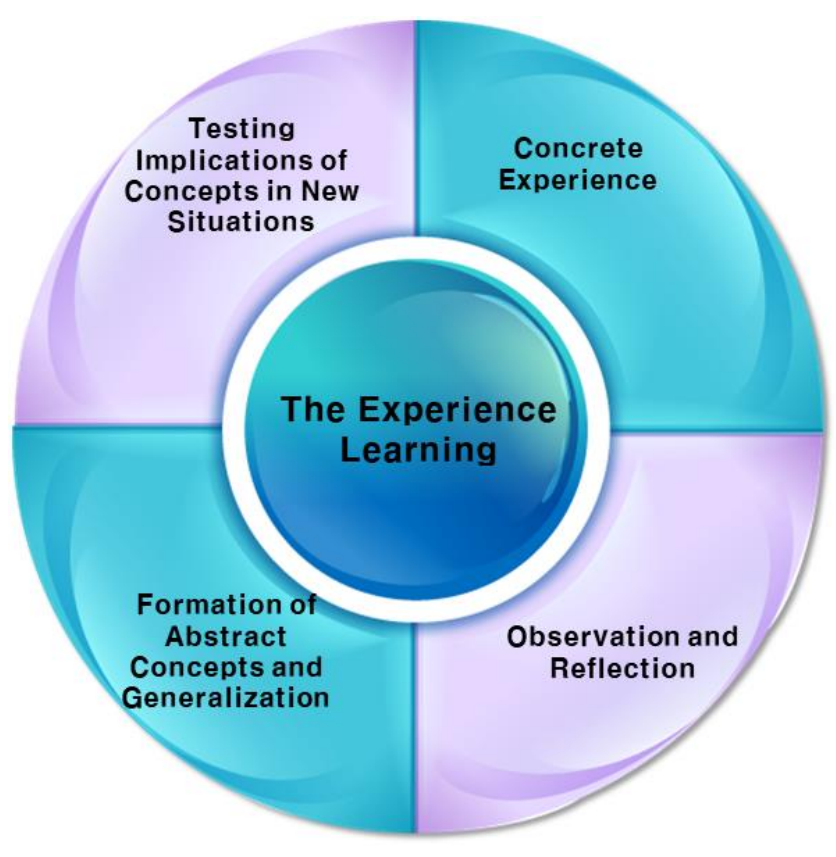

[Fig.1] The Experience Learning Cycle[10]

Previous studies have argued that efforts to improve the quality of service learning should be emphasized rather than emphasizing external aspects such as administrative and financial support. Through this, it is possible to confirm the relationship between school education and service learning 
in subjects, educational contents, teaching and learning methods, and evaluation. In other words, it is necessary to select educational content that reflects the student's previous experiences.

In terms of teaching and learning, it is necessary to plan the results expected by students in advance and design them so that systematic learning is possible. In terms of evaluation, it is necessary to check whether the goal of the curriculum has been achieved in connection with the activity and to find a way to record it physically.

\section{Research Method}

\subsection{Data analysis Model}

This study analyzed the existing plan based on the ADDIE curriculum development model. The ADDIE Model is the base model of the Indicative System Design. The ADDIE model is named after the first letter of each phase of "analyze, design, develop, implement and evaluate"[11]. A systematic approach model that analyzes the curriculum for implementation, looks for solutions, designs, develops, implements, and evaluates results. [Fig. 2] shows that all five processes, components of the ADDIE guidance design model.

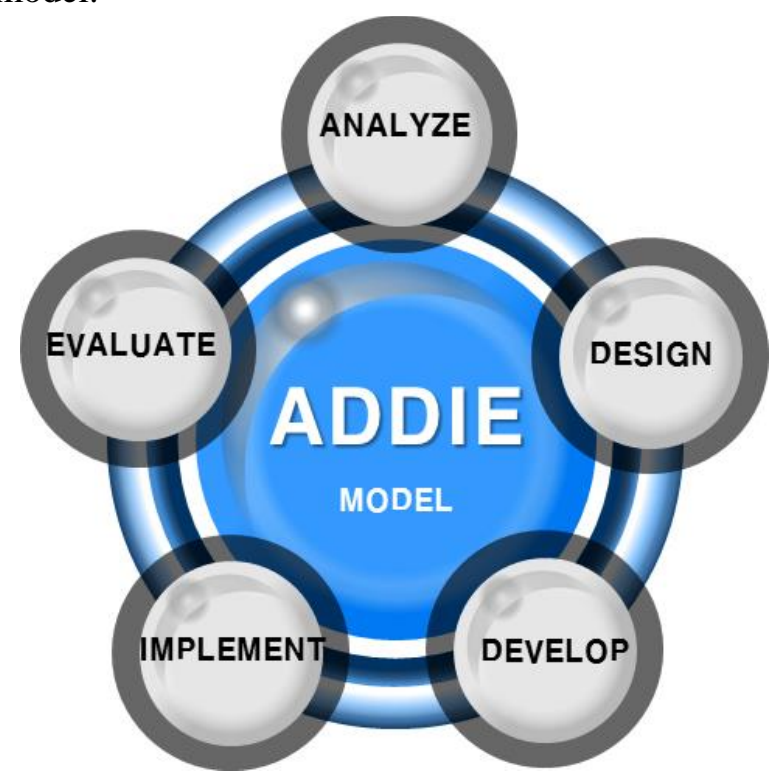

[Fig. 2] ADDIE Model [12]

There are five characteristics of the ADDIE guidance design model. First, it is systematic. Being systematic means that each part is structured and organized to form a unified whole. A closer look at the ADDIE model shows that the steps follow a specific logical sequence and thus have systematic characteristics. Second, it is dynamic. A dynamic interaction and holistic understanding of the ADDIE model includes critical processes for successful goal execution. Third, it is reliable. The ADDIE model is highly reliable because the same steps can be performed regardless of the specific designer, location, etc. Fourth, it is iterative. This is because the ADDIE model is highly likely to be repeated indefinitely from stage of the analysis to evaluation. Finally, it is empirical. The ADDIE model has empirical characteristics because it makes effective decisions over time based on various data.

\section{2 analysis Data Frame}

Core competencies: the 2015 revised curriculum outline introduces the following core 
competencies. This study sets the following core competencies of the curriculum as the educational goal of service learning.

To embody the vision of an educated person, the following key competencies are targeted to be promoted through the entire process of education.

A. Self-management competency to lead one's life with self-identity and confidence based on basic abilities and qualifications necessary for life and career.

B. Knowledge-information processing skills to process and utilize knowledge and information from diverse fields to solve problems in reasonable ways.

C. Creative thinking skills to discover something novel by integrating knowledge, skills, and experiences from diverse professional fields on the basis of broad foundational knowledge.

D. Aesthetic-emotional competency to find and appreciate the meanings and values of life, based on an empathetic understanding of others and cultural sensitivities.

E. Communication skills to respectfully listen to opinions of others and effectively express one's thoughts and feelings in diverse situations.

F. Civic competency to actively participate in improving the community with values and attitudes required to be a member of local, national, and global communities.

[Fig. 3] A Screen Capture of 2015 Curriculum Document [13]

Achievement standards: in the 2015 revised curriculum, the achievement standards are coded and presented as follows (Example of social studies and integrated social studies subjects). This study is based on linking achievement standards in setting educational goals linked to service learning subjects.

(8) 경제생활과 선택

인간의 경제생활을 생산, 분배, 소비를 중심으로 이해하고, 희소성으로 인해 발생하는 경제 문제를 합리젹으로 해결할 수 있는 능력을 함양한다. 경제 문제의 해결이 경제 체제에 따라 달라짐을 이해하 고, 자유 시장경제에서 핵심적인 두 축인 기업 활동과 금응 생활의 중요성을 인식한다.

[9사(일사)08-01] 경제활동에서 희소성으로 인한 합리젹 선택의 펠요성을 이해하고 기본젹인 경제 문제 해결을 위한 방식으로서 경제체제의 특징을 분석한다.

[9사(일사)08-02] 자유 시장경제에서 기업의 역할과 사회적 책임을 이해하고, 기업가 정신을 함양할 수 있는 태도를 각는다.

[9사(일사)08-03] 일생 동안 이루어지는 경제생활을 조사하고, 경제적으로 지속가능한 생활을 위한 금응 생활(자산 관리, 신용 관리)의 중요성을 이해한다.

[Fig. 4] Screen Capture of 2015 Curriculum Document [14] 
Curriculum documents are open to the public and can be accessed through the National Curriculum Information Center (http://www.ncic.go.kr/)

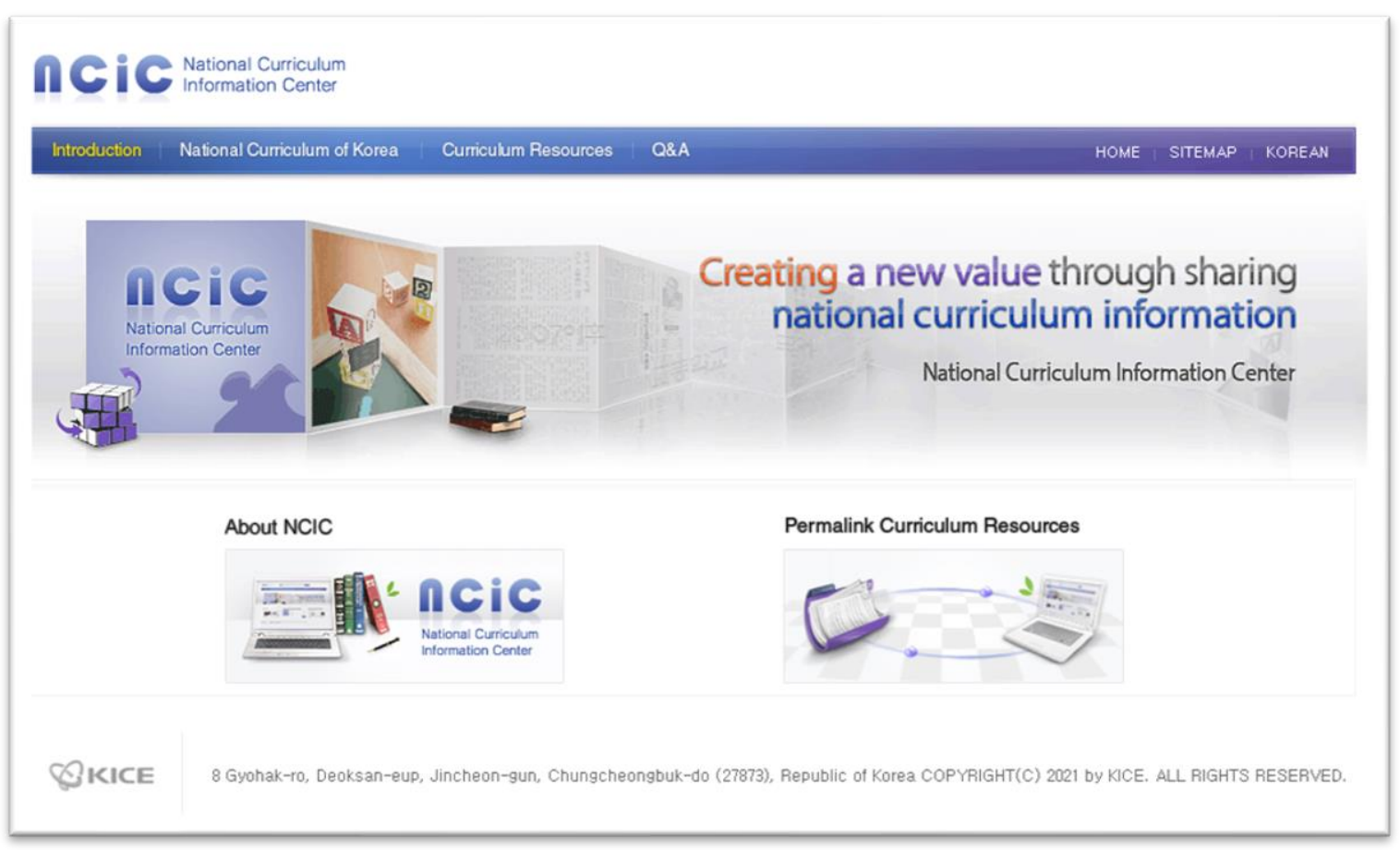

[Fig. 5] A screen Capture of 2015 Curriculum Document [15]

The collected data went through an internal review by the research team and a practical verification process through the Teachers' Expert Council. The model was revised in detail by collecting opinions from volunteer groups and school sites.

\section{Result}

Based on the data, the study developed the following template. The developed template is designed with the user in mind first. In addition, it was possible to index the connection between volunteer work and education. Specifically, it provides a visual representation of how the content of the curriculum relates to the activity. The relationship between core competencies and activities was also clearly expressed. The template was designed so that it can be connected naturally with the educational content. It also shows the content and activity with a simple check. Margins have been provided for teachers to fill in narrative form.

\begin{tabular}{|c|c|c|c|}
\hline No. & & & \\
\hline $\begin{array}{r}\text { progran } \\
\text { subject }\end{array}$ & & & \\
\hline \multirow[t]{2}{*}{$\begin{array}{l}\text { Target } \\
\text { grade }\end{array}$} & \multirow[t]{2}{*}{$\begin{array}{l}\square \text { Middle School } \\
\square \text { HighSchool }\end{array}$} & $\begin{array}{l}\text { planning } \\
\text { entity }\end{array}$ & $\begin{array}{l}\square \text { Student Planning Type } \\
\square \text { External (center/local organization) program } \\
\text { participation type }\end{array}$ \\
\hline & & difficulty & $\square$ Low $\square$ Middle $\square$ High \\
\hline
\end{tabular}




\begin{tabular}{|c|c|c|c|}
\hline $\begin{array}{c}\text { education } \\
\text { organization }\end{array}$ & $\begin{array}{l}\square \text { Creative experience activities } \\
\text { according to the school education plan } \\
\square \text { Other activities }\end{array}$ & $\begin{array}{l}\text { activity } \\
\text { scale }\end{array}$ & $\begin{array}{l}\square \text { Individual } \square \text { Club } \\
\square \text { Class } \square \text { Grade } \square \text { School }\end{array}$ \\
\hline activity time & & $\begin{array}{l}\text { place of } \\
\text { activity }\end{array}$ & $\square \quad$ On-campus $\square$ Off-campus \\
\hline
\end{tabular}

\begin{tabular}{|c|c|c|}
\hline service value & \multicolumn{2}{|c|}{$\begin{array}{l}\square \text { Fostering democratic citizens } \square \text { Improving career development skills } \\
\square \text { Improving self-efficacy } \square \text { Improving attitude toward solving social problems } \\
\square \text { Others }\end{array}$} \\
\hline \multirow{3}{*}{ activity goal } & subjects & $\begin{array}{l}\square \text { Korean } \square \text { Mathematics } \square \text { English } \square \text { Korean History } \square \text { Society } \square \text { History } \square \text { Ethics } \\
\square \text { Science } \\
\square \text { Physical Education } \square \text { Music } \square \text { Art } \square \text { Technology/Home } \square \text { Second Foreign } \\
\text { Language } \square \text { Chinese } \square \text { Liberal Arts }\end{array}$ \\
\hline & competencies & $\begin{array}{l}\square \text { Self-management capability } \square \text { Knowledge information processing capability } \square \\
\text { Creative thinking capability } \\
\square \text { Aesthetic emotional competence } \square \text { Communication competence } \square \text { Community } \\
\text { competence }\end{array}$ \\
\hline & topics & $\begin{array}{l}\square \text { Safety and Health } \square \text { Personality } \square \text { Career } \square \text { Democratic Citizen } \\
\square \text { Human Rights } \square \text { Multicultural } \square \text { Unification } \square \text { Dokdo } \\
\square \text { Economics/Financial } \square \text { Environment/Sustainable Development }\end{array}$ \\
\hline $\begin{array}{l}\text { Curriculum- } \\
\text { related } \\
\text { content }\end{array}$ & & \\
\hline
\end{tabular}

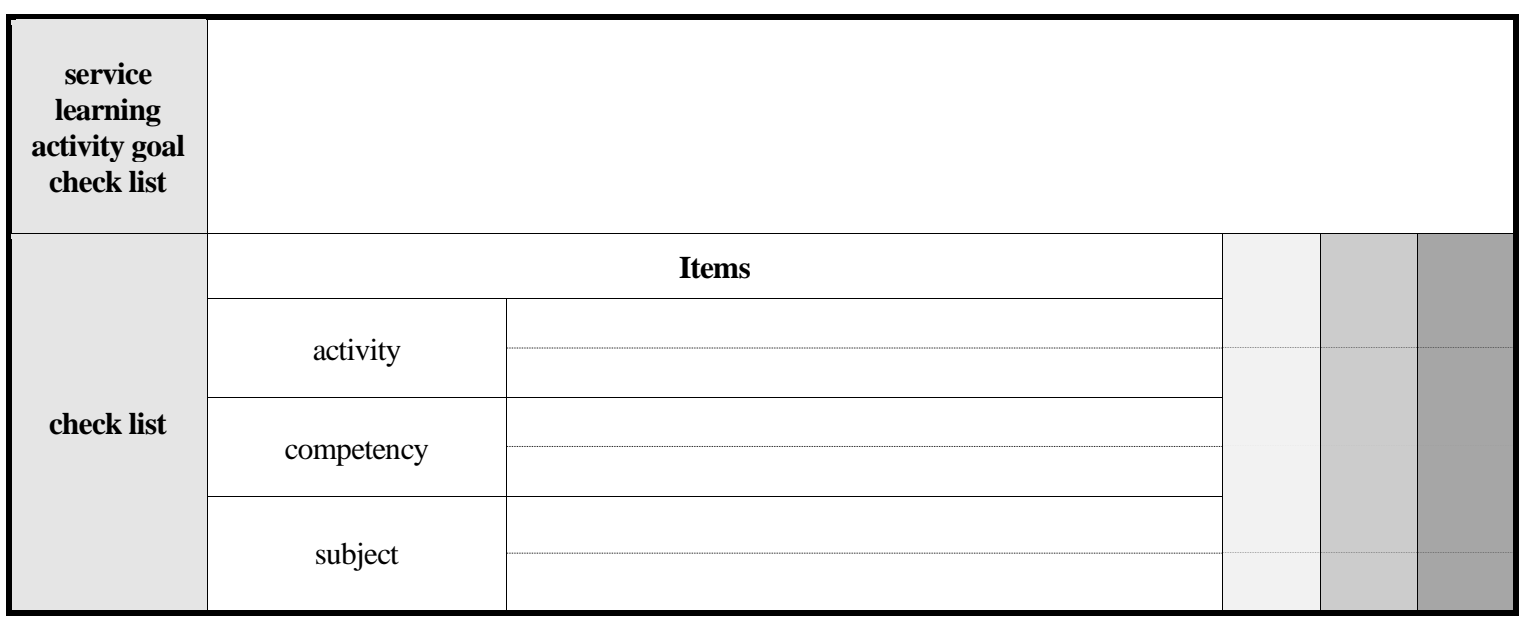

\section{Remarks \\ Record \\ Contents \\ (example)}

[Fig. 6] A Template Model for Linking Service Learning and School Curriculum

A template used as an example is presented as follows. 


\begin{tabular}{|c|c|c|c|}
\hline No. 01 & & & \\
\hline $\begin{array}{c}\text { program } \\
\text { subject }\end{array}$ & \multicolumn{3}{|c|}{ No Food Left Behind Campaign } \\
\hline \multirow[t]{2}{*}{$\begin{array}{l}\text { Target } \\
\text { grade }\end{array}$} & \multirow[t]{2}{*}{$\begin{array}{l}\square \text { Middle School } \\
\square \text { HighSchool }\end{array}$} & $\begin{array}{l}\text { planning } \\
\text { entity }\end{array}$ & $\begin{array}{l}\square \text { Student Planning Type } \\
\square \text { External (center/local organization) } \\
\text { program participation type }\end{array}$ \\
\hline & & difficulty & $\square$ Low $\square$ Middle $\square$ High \\
\hline $\begin{array}{l}\text { education } \\
\text { organization }\end{array}$ & $\begin{array}{l}\square \text { Creative experience activities } \\
\text { according to the school education plan } \\
\square \text { Other activities }\end{array}$ & $\begin{array}{l}\text { activity } \\
\text { scale }\end{array}$ & $\begin{array}{l}\square \text { Individual } \square \text { Club } \\
\square \text { Class } \square \text { Grade } \square \text { School }\end{array}$ \\
\hline activity time & 3 hours in total (3rd to 4 th class) & $\begin{array}{l}\text { place of } \\
\text { activity }\end{array}$ & $\square$ On-campus $\square$ Off-campus \\
\hline
\end{tabular}

\begin{tabular}{|c|c|c|}
\hline service value & \multicolumn{2}{|c|}{$\begin{array}{l}\square \text { Fostering democratic citizens } \square \text { Improving career development skills } \\
\square \text { Improving self-efficacy } \square \text { Improving attitude toward solving social problems } \\
\square \text { Others (enhance eco-friendly awareness) }\end{array}$} \\
\hline \multirow{3}{*}{ activity goal } & subjects & $\begin{array}{l}\square \text { Korean } \square \text { Mathematics } \square \text { English } \square \text { Korean History } \square \text { Society } \square \text { History } \\
\square \text { Ethics } \square \text { Science } \\
\square \text { Physical Education } \square \text { Music } \square \text { Art } \square \text { Technology/Home } \square \text { Second Foreign } \\
\text { Language } \square \text { Chinese } \square \text { Liberal Arts }\end{array}$ \\
\hline & competencies & $\begin{array}{l}\square \text { Self-management capability } \square \text { Knowledge information processing capability } \square \\
\text { Creative thinking capability } \\
\square \text { Aesthetic emotional competence } \square \text { Communication competence } \square \text { Community } \\
\text { competence }\end{array}$ \\
\hline & topics & $\begin{array}{l}\square \text { Safety and Health } \square \text { Personality } \square \text { Career } \square \text { Democratic Citizen } \\
\square \text { Human Rights } \square \text { Multicultural } \square \text { Unification } \square \text { Dokdo } \\
\square \text { Economics/Financial } \square \text { Environment/Sustainable Development }\end{array}$ \\
\hline \multirow[b]{2}{*}{$\begin{array}{l}\text { Curriculum- } \\
\text { related } \\
\text { content }\end{array}$} & $\begin{array}{c}\text { practical } \\
\text { mathematics }\end{array}$ & $\begin{array}{l}\text { [12PM01-01]Find rules in various phenomena and express them as expressions. } \\
\text { [12PM01-02]Understand the meaning of formulas used in everyday life. }\end{array}$ \\
\hline & $\begin{array}{l}\text { exercise and } \\
\text { health }\end{array}$ & $\begin{array}{l}\text { [12EH01-01] Learn how to manage health necessary to form a healthy lifestyle based } \\
\text { on your understanding of lifestyle and health management. } \\
\text { [12EH02-02] Based on the concept of metabolic rate due to lifestyle-related diseases } \\
\text { and lack of exercise, an exercise plan necessary for obesity prevention and management } \\
\text { is established, and continuous exercise is applied to obesity management. }\end{array}$ \\
\hline
\end{tabular}

\begin{tabular}{|c|c|c|c|c|}
\hline $\begin{array}{c}\text { service } \\
\text { learning } \\
\text { activity goal } \\
\text { check list }\end{array}$ & $\begin{array}{c}|c| \\
\text { OMeasure your body mass index to determine your degree of obesity and check your healthy eating } \\
\text { habits. }\end{array}$ \\
\hline \multirow{2}{*}{ check list } & Suggest an appropriate amount of meals according to the index, and prepare and practice volunteer \\
activities for the rest of the day. & \multicolumn{1}{|c|}{ Items } & & \\
\cline { 2 - 5 } & $\begin{array}{l}\text { 1. Can you measure your body mass index to } \\
\text { aetermine if you are overweight and check your } \\
\text { healthy eating habits? }\end{array}$ & $\begin{array}{l}\text { 2. Can you suggest an appropriate amount of meals } \\
\text { according to the index and prepare and practice } \\
\text { volunteer activities for the rest of the day? }\end{array}$ & $\mid$ \\
\hline
\end{tabular}




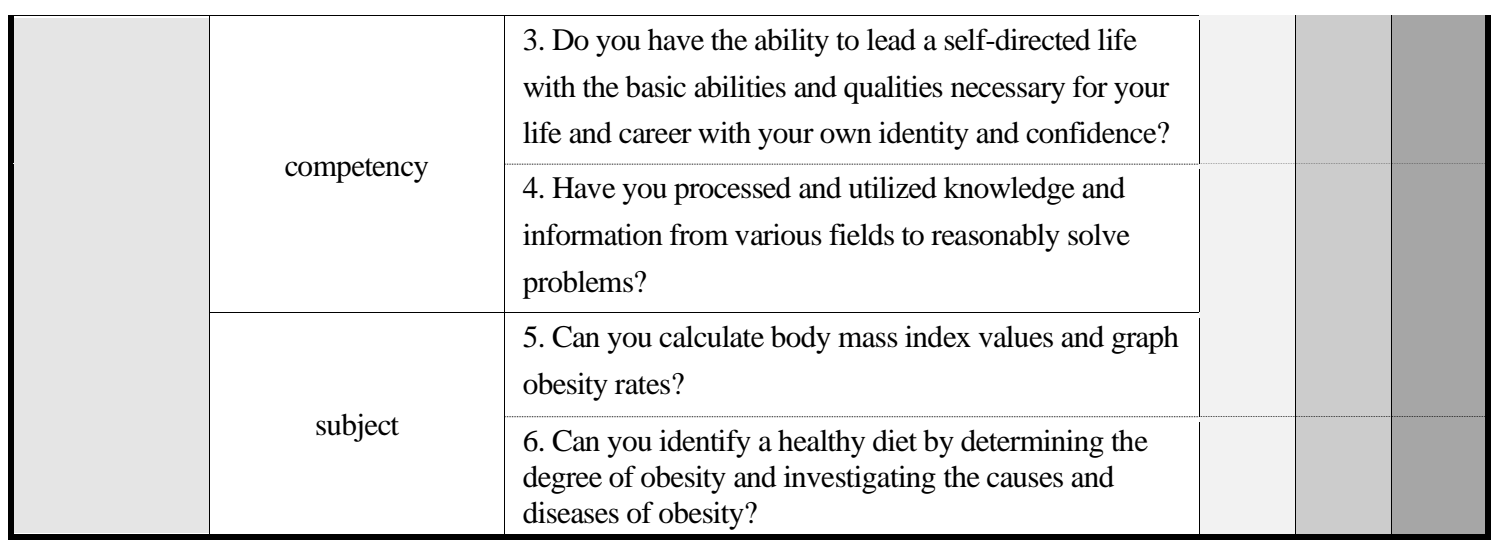

\begin{tabular}{|c|c|}
\hline $\begin{array}{l}\text { Remarks } \\
\text { Record } \\
\text { Contents } \\
\text { (example) }\end{array}$ & $\begin{array}{l}\text { The body mass index was measured to determine the degree of obesity, confirmed healthy eating habits, } \\
\text { suggested appropriate meals according to the index, and prepared and practiced volunteer activities for } \\
\text { the rest of the day. Through this, they gain self-identity and self-confidence, acquire basic abilities and } \\
\text { qualities necessary for life and work, and have the ability to lead a self-directed life. Knowledge } \\
\text { information processing ability has been cultivated. }\end{array}$ \\
\hline
\end{tabular}

[Fig. 7] An Example of a Service LearningRecord using a Template

In this example, achievement standards are used. It is easy to use textbooks when presenting achievement standards. In other words, looking at the service learning plan makes it easy for students and teachers to see if which content is relevant.

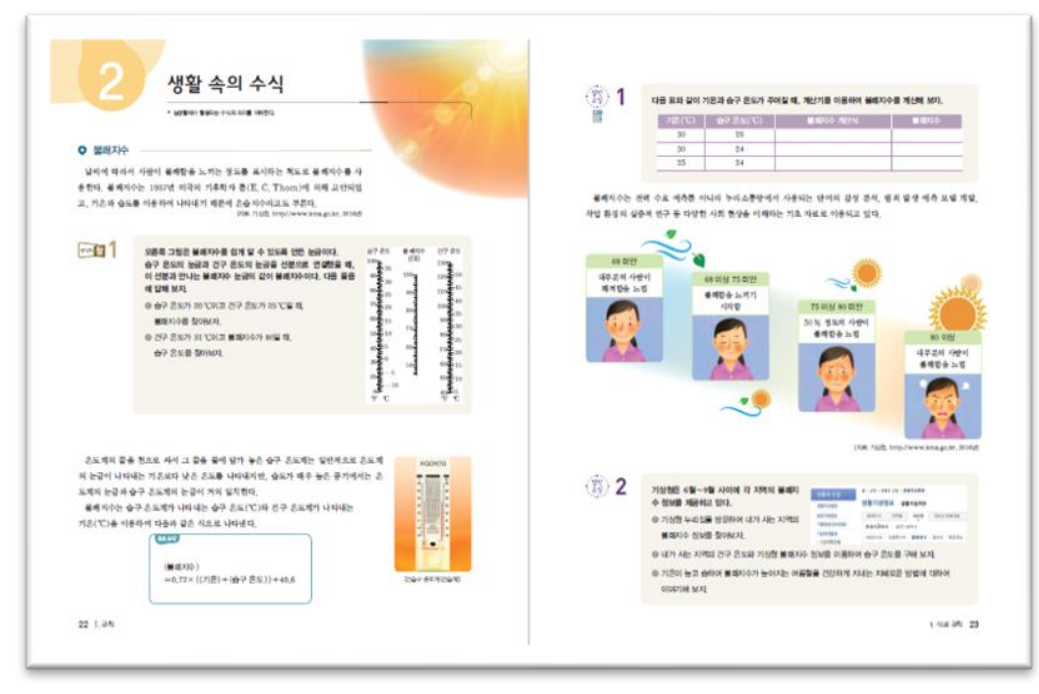

[Fig. 8] Mathematics Textbook Linked to Achievement Standards [16]

\section{Conclusion}

Recently, a plan to revise the national curriculum in 2022 has been announced. Service learning is expected to change greatly in curriculum revisions. At this time of change, it is necessary to diagnose the direction in which service learning should be undertaken. Service learning is not just an activity for it is done in a way that develops students' ability to solve problems on their own. But this is not easy. Although teachers understand the meaning of service learning and recognize the need for educational cooperation, actual cooperation is difficult. In particular, because the college entrance exam is important in schools, there are many restrictions in realizing service learning. Given this reality, 
student volunteer activities should be developed along with educational content.

There are many ways to connect educational content to volunteer work. Accordingly, teachers have continously requested to develop a standardized template. This study was conducted to meet that need.The use of this template serves as a bridge between volunteers, students and school teachers. In a previous study, these three subjects wanted to communicate with each other, but did not know what to do or how to communicate. Using this template, volunteers, students and school teachers might be able to organize educational goals, contents, methods, evaluation methods, etc. at a glance. In addition, by accumulating these results, it will be possible to determine the degree of correlation between educational content and volunteer work that is statistically significant. Based on this model, service learning is expected to become more active.

\section{Acknowledgments}

This work was supported by Hankuk University of Foreign Studies Research Fund.

This study was written by modifying a part of "A Study on the Model Study of the Curriculum Linkage of the Youth Service Learning School through the Analysis of the Seoul-type Service Learning Practice School Program", in which the researcher participated as the principal researcher.

\section{References}

[1] J. Y. Lim, Y. M. Lee, Direction and Challenges of High Skills Vocational Education and Training Policies in Response to Future Social Changes, International Journal of Computer Science and Information Technology for Education, (2016), Vol.1, No.1, pp.7-14, DOI: http://dx.doi.org/10.21742/IJCSITE.2016.1.1.02.

[2] S. H. Kim, Comparative Analysis of United States and South Korean High School, Asia-Pacific Journal of Educational Management Research, (2020), Vol.5, No.2, pp.35-40.

[3] S. Hong, S. Bae, Factors Related to Test Anxiety for Studying TOEIC among College Student of Health Affiliated Educations, International Journal on Consulting Psychology for Patients, (2018), Vol.2. No.2, pp.19-26, DOI: http://dx.doi.org/10.21742/IJCPP.2018.2.2.04

[4] S-Y. Chun, W. Grift, Birth of University: Different Stories in Asia and Europe, International Journal of Computer Science and Information Technology for Education, (2016), Vol.1, No.1, pp.23-28, DOI: http://dx.doi.org/10.21742/IJCSITE.2016.1.1.04.

[5] Y. H. Cho, A Study on Theoretical Framework of College Volunteering with special reference on service learning, Korean Journal of Youth Studies, (2002), Vol.9, No.3, pp.243-268.

[6] W. P. Hong, How to enhance the educative function of school-based community service: Integrating service and learning, The Journal of Curriculum Studies, (2013), Vol.31, No.3, pp.227-251, DOI: 10.15708/kscs.31.3.201309.010

[7] J. C. Kielsmeier, Build a bridge between service and learning, Phi Delta Kappan, (2010), Vol.91, No.5, pp.8-15.

[8] D. J. Kim, Effects of volunteer activities on social development in adolescence, Korean Academy of Social Welfare Support, (2009), Vol.4, No.1, pp.123-146.

[9]S. H. Billig, Research on K-12 School-Based Service-Learning: The Evidence Builds, Phi Delta Kappan, Vol.81, No.9, pp.658-664, https://eric.ed.gov/?id=EJ606453

[10] Alice Y. Kolb, and David A. Kolb, The Kolb learning style inventory-version 3.12005 technical specifications. USA Boston, MA: Hay Resource Direct, (2005)

[11] R. M. Branch, Instructional design: The ADDIE approach, (2010), German: Springer Science Business Media, LLC

[12] B. A. Jones, ADDIE model (Instructional design), (2014), http://citeseerx.ist.psu.edu/viewdoc/summary? 
doi $=10.1 \cdot 1.572 .4041$

[13] Ministry of Education, The National Curriculum for the Primary and Secondary Schools, Proclamation of the Ministry of Education \#2015-74, Korea: Ministry of Education, (2015).

[14] Ministry of Education, Social Studies Curriculum, (2015), https://www.edunet.net/nedu/ncicsvc/listSub2015Form. do?menu_id=623\#

[15] http://www.ncic.go.kr/english.index.do;jsessionid=A9F6504D3C268077B0DD8AC991F4BDAA, Apr 05 (2021)

[16] J. Y. Lee, High School Practical Mathematics Textbook, (2019), Chunjae, p.22-25. 